\title{
Scientific Advances in Controlling Nosema ceranae (Microsporidia) Infections in Honey Bees (Apis mellifera)
}

\author{
Andre J. Burnham* \\ Emory University, Atlanta, GA, United States
}

Honey bees (Apis mellifera) are agriculturally important pollinators that have been recently at risk to severe colony losses. A variety of parasites and pathogens have been linked to colony decline, including the microsporidian parasite Nosema ceranae. While fumagillin has been used to control nosemosis in managed honey bee colonies for decades, research shows that this antibiotic poses a toxic threat and that its efficacy against $N$. ceranae is uncertain. There is certainly a demand for a new veterinary medication to treat honey bee colonies infected with $N$. ceranae. In this review, recent scientific advances in controlling $N$. ceranae infections in honey bees are summarized.

OPEN ACCESS

Edited by:

Deirdre P. Campion,

University College Dublin, Ireland

Reviewed by:

Jevrosima Stevanovic, University of Belgrade, Serbia

Wei-Fone Huang,

Fujian Agriculture and Forestry

University, China

*Correspondence:

Andre J. Burnham burnhamandre@gmail.com

Specialty section: This article was submitted to Veterinary Pharmacology and

Toxicology,

a section of the journal

Frontiers in Veterinary Science

Received: 20 December 2018 Accepted: 25 February 2019 Published: 15 March 2019

Citation:

Burnham AJ (2019) Scientific

Advances in Controlling Nosema ceranae (Microsporidia) Infections in

Honey Bees (Apis mellifera).

Front. Vet. Sci. 6:79.

doi: 10.3389/fvets.2019.00079
Keywords: honey bee, Nosema ceranae, nosemosis, fumagillin, RNA interference, phytotherapy, colony collapse disorder

\section{INTRODUCTION}

Honey bees (Apis mellifera) are pollinators with a significant worldwide economic value and are responsible for the pollination of many ecologically and agriculturally important crops $(1,2)$. Managed honey bee colonies have been in decline for the past several decades, notably in North America $(3,4)$. This decline is of growing concern on account of the crucial role honey bees play in sustaining human and livestock food sources $(2,5)$. Colony losses have been linked to pesticide exposure, environmental and migratory stress, and poor nutrition; however, parasite and pathogen infections are likely the leading factors contributing to colony mortality $(4,6-12)$.

Nosema ceranae is an obligate microsporidian intracellular parasite infectious to honey bees (13-15). While Nosema apis and N. ceranae both parasitize honey bees, $N$. ceranae has geographically outcompeted $N$. apis (16-20). Severe $N$. ceranae infections (nosemosis) can cause bee mortality and have been correlated with colony losses $(7,13,15,21-24)$. N. ceranae is also associated with morbid physiological impairments including suppressed immune function, foraging behavior, pheromone and hormone production, and lipid synthesis (25-30).

A spore-forming fungal parasite, $N$. ceranae is transmitted orally via honey, nectar, pollen and bee fecal matter (31). The reproductive cycle of Nosema begins shortly after entering the host digestive tract $(24,31,32)$. Following germination in the midgut lumen, environmental osmotic pressure causes a specialized organelle called a polar tube to protrude from the spore and inject sporoplasm (infectious material) into the host cytoplasm $(32,33)$. Meronts then proliferate and mature into primary spores which germinate within the host cell and may auto-infect adjacent cells $(24,33,34)$. Primary spores may also develop into fully-formed environmental spores that are released via cell lysis into the midgut lumen $(24,33)$. Here the reproductive cycle repeats, or free spores are expelled by defecation (31). 
As livestock, honey bees require veterinary treatments from beekeepers or agriculturists when infected with parasites or pathogens (35, 36). First isolated in 1949 from the fungus Aspergillus fumigatus, fumagillin has been used to treat nosemosis induced by $N$. apis in honey bees for several decades (37). However, recent studies show that this antibiotic may be ineffective against $N$. ceranae infections (38-43). There is also evidence that fumagillin is fairly toxic and causes chromosomal aberrations, carcinogenicity in humans, and alterations to the ultrastructure of hypopharyngeal glands in bees (37). Consequentially, many countries outside of the Americas (including the European Union) have banned fumagillin for agricultural use (MRL; Commission Regulation, EU, 2010, no. $37 / 2010$ ). There is a significant demand, therefore, for a new medication that safely and effectively treats honey bee colonies infected with $N$. ceranae. Recent molecular, phytotherapeutic, and supplement-based scientific advances that aim to control nosemosis in honey bees (Table 1) are summarized and discussed herein.

\section{SMALL MOLECULES}

Studying the biological activity of small molecules presents a promising strategy for discovering a new anti-Nosema therapy. A novel $N$. ceranae cell culture procedure can be adapted to a 96-well microplate format, thus making high and medium throughput drug screening assays on $N$. ceranae feasible and efficient (44). Two nitroimidazole compounds (metronidazole and tinidazole) that greatly reduce $N$. ceranae viability in vitro with low cytotoxicity have been identified using this method (44). While the method described could be useful in screening a high number of molecules, the likelihood of applying these two compounds to apiarian medicine is low, as nitroimidazole compounds are unapproved by many countries for use in treating food animals (MRL; Commission Regulation, EU, 2010, no. 37/2010). A more current study tested both in vitro and in vivo activity of porphyrins against $N$. ceranae. Porphyrins are aromatic heterocyclic compounds conserved in nature that are involved in many biological processes, including oxygen transport and photosynthesis (45). Treating spores and infected bees with select non-metallated porphyrins $\left[\mathrm{PP}(\mathrm{Asp})_{2}\right.$ and $\mathrm{TMePyP}]$ in sugar syrup significantly reduced microsporidian viability in vitro, decreased infection levels of inoculated honey bees by up to 5 fold, and increased bee survival $\left[\mathrm{PP}(\mathrm{Asp})_{2}\right.$ only; (45)]. The investigators postulate that porphyrins may act on the cell wall or membrane, as deformities in spore exosporium layers were observed following spore pretreatments.

It is noteworthy that inhibition of the enzyme methionine aminopeptidase type 2 (MetAP2) is fumagillin's proposed mechanism of action against Nosema (37, 42, 46). MetAP2 specifically catalyzes the cleavage of initiator methionine on the $\mathrm{N}$-terminal of newly-synthesized proteins, serving an important function in post translational modification (69). Although most animals express two functional MetAP isoforms (MetAP1 and MetAP2), microsporidia express only MetAP2 (69). Therefore, use of MetAP2 antagonists to target Nosema could be a viable strategy for controlling nosemosis in honey bees. Van den Heever et al. (46) recently screened several analogs of fumagillin (and other commercially-available compounds) in cage experiments and observed a significant decrease in N. ceranae loads. Although the authors demonstrate efficacy, none of the compounds tested were as effective as fumagillin at eliminating $N$. ceranae spores. Given the tight regulation on use of antibiotics in food animals, precautions should be taken in the development and approval of novel MetAP2 inhibitors for apiary medicine.

Repurposing currently-used honey bee medications may be another favorable strategy for controlling $N$. ceranae. Oxalic and formic acid, which are used as miticides by beekeepers to suppress varroa mites (devastating honey bee ectoparasites), have inactivated $N$. ceranae in both laboratory and field trials $(47,48)$. In an indoor fumigation experiment, Underwood and Currie (47) noted that formic acid fumigation lowered Nosema spore loads in colonies over the course of 1 year. Indoor fumigation treatments, while potentially efficacious, are probably not cost-effective nor practical on a commercial beekeeping level. A more practical method would be to implement natural fumes or vapors created by solubilized or liquid compounds, similar to topical varroa mite treatments [formic acid, oxalic acid, etc.; (36)]. Nanetti et al. (48) applied this concept, finding oral oxalic acid $(0.25 \mathrm{M}$ in sugar syrup) treatments in caged bees and topical treatments in field trials to significantly decrease the rate of infection and increase colony survival compared to controls. These findings are notable since varroa mites are usually controlled by topical, non-oral treatments (36). Use of a topical, fume-generating treatments may have advantages over oral medications since delivery is not subject to variable feeding behavior (storing, hording, poor winter feeding, etc.). Other phenolic compounds commonly used to combat varroa mite infestations, particularly resveratrol and thymol $(35,36)$, are effective at inhibiting $N$. ceranae in oral preparations $(46,49,50)$. Larger colony survival surveys and toxicity studies are still required for these treatments. Together, these studies suggest that certain organic acids, phenolics and other compounds impede $N$. ceranae viability and may have duel treatment applications given the continuing need for miticides in apiarian medicine.

Most experimental Nosema treatments target spores in the honey bee digestive tract, leaving viable spores in hive structures, nectar combs, and feces free to infect or re-infect naïve or treated animals. Consequentially, future studies could more thoroughly investigate dosage and synergy between treatment types that target spores in various life stages. Pairing fumegenerating topical treatments (e.g., oxalic acid-soaked pads) with oral medications, for example, may kill both reproducing and free spores in the hive environment, while also controlling varroa mites.

\section{RNA INTERFERENCE}

Investigating RNAi may be of use in the discovery of novel targets and treatments for honey bee $N$. ceranae infections. RNAi is a post transcriptional gene silencing mechanism that is driven by double-stranded RNA (dsRNA) binding to 
TABLE 1 | A summary and comparison of anti-N. ceranae treatments that have displayed efficacy in previous works.

\begin{tabular}{|c|c|c|c|c|c|}
\hline Treatment type & Bee spore load ${ }^{1}$ & Bee survival ${ }^{1}$ & Hive spore load ${ }^{2}$ & Other effects & References \\
\hline \multicolumn{6}{|l|}{ SMALL MOLECULES } \\
\hline Metronidazole (in vitro only) ${ }^{\star \star}$ & $\mathrm{N} / \mathrm{A}$ & $\mathrm{N} / \mathrm{A}$ & $\mathrm{N} / \mathrm{A}$ & $\downarrow$ spore viability & $(44)$ \\
\hline Tinidazole (in vitro only) ${ }^{\star \star}$ & $\mathrm{N} / \mathrm{A}$ & $\mathrm{N} / \mathrm{A}$ & $\mathrm{N} / \mathrm{A}$ & $\downarrow$ spore viability & $(44)$ \\
\hline Porphyrin: PP(Asp)2 & $\downarrow$ & $\uparrow$ & $\mathrm{N} / \mathrm{A}$ & $\downarrow$ spore viability & $(45)$ \\
\hline Porphyrin: TMePyP & $\downarrow$ & $\mathrm{N} / \mathrm{A}$ & $\mathrm{N} / \mathrm{A}$ & $\downarrow$ spore viability & $(45)$ \\
\hline Fumagillin analogs $\mathrm{a}^{\star}$ & $\downarrow$ & $\dagger$ & $\mathrm{N} / \mathrm{A}$ & $\mathrm{N} / \mathrm{A}$ & $(46)$ \\
\hline Fumagillol $^{\star}$ & $\downarrow$ & $\dagger$ & $\mathrm{N} / \mathrm{A}$ & $\mathrm{N} / \mathrm{A}$ & $(46)$ \\
\hline Semisynthetic aspirin & $\downarrow$ & $\dagger$ & $\mathrm{N} / \mathrm{A}$ & $\mathrm{N} / \mathrm{A}$ & $(46)$ \\
\hline Enilconazole $^{*}$ & $\downarrow$ & $\dagger$ & $\mathrm{N} / \mathrm{A}$ & $\mathrm{N} / \mathrm{A}$ & $(46)$ \\
\hline Piperonyl analog* & $\downarrow$ & $\dagger$ & $\mathrm{N} / \mathrm{A}$ & $\mathrm{N} / \mathrm{A}$ & $(46)$ \\
\hline Thymol* $^{*}$ & $\downarrow$ & $\dagger$ & $\mathrm{N} / \mathrm{A}$ & $\mathrm{N} / \mathrm{A}$ & $(46)$ \\
\hline Formic acid (fumigation) & $\mathrm{N} / \mathrm{A}$ & $\mathrm{N} / \mathrm{A}$ & $\downarrow$ & $\mathrm{N} / \mathrm{A}$ & $(47)$ \\
\hline Oxalic acid & $\downarrow$ & $\mathrm{N} / \mathrm{A}$ & $\mathrm{N} / \mathrm{A}$ & $\mathrm{N} / \mathrm{A}$ & $(48)$ \\
\hline Oxalic acid (topical field trial) & $\mathrm{N} / \mathrm{A}$ & $\mathrm{N} / \mathrm{A}$ & $\downarrow$ & $\uparrow$ colony survival & $(48)$ \\
\hline Thymol & $\downarrow$ & $\uparrow$ & $\mathrm{N} / \mathrm{A}$ & $\mathrm{N} / \mathrm{A}$ & $(49)$ \\
\hline Resveratrol & No Effect & $\uparrow$ & $\mathrm{N} / \mathrm{A}$ & $\mathrm{N} / \mathrm{A}$ & (49) \\
\hline Thymol & $\downarrow$ & No Effect & $\mathrm{N} / \mathrm{A}$ & $\mathrm{N} / \mathrm{A}$ & $(50)$ \\
\hline Resveratrol & $\downarrow$ & $\uparrow$ & $\mathrm{N} / \mathrm{A}$ & $\mathrm{N} / \mathrm{A}$ & $(50)$ \\
\hline \multicolumn{6}{|l|}{ RNA INTERFERENCE } \\
\hline ADP/ATP transporter RNAi & $\downarrow$ & $\mathrm{N} / \mathrm{A}$ & $\mathrm{N} / \mathrm{A}$ & 个response to sucrose & $(51)$ \\
\hline ptp3 RNAi & $\downarrow$ & $\uparrow$ & $\mathrm{N} / \mathrm{A}$ & $\uparrow$ immune expression & $(52)$ \\
\hline nkd RNAi & $\downarrow$ & $\uparrow$ & $\mathrm{N} / \mathrm{A}$ & $\uparrow$ immune expression & $(53)$ \\
\hline \multicolumn{6}{|l|}{ EXTRACTS AND SUPPLEMENTS } \\
\hline Polysaccharide extracts ${ }^{\star}$ & $\downarrow$ & $\uparrow$ & $\mathrm{N} / \mathrm{A}$ & $\mathrm{N} / \mathrm{A}$ & $(54)$ \\
\hline Pentadecapeptide BPC 157 & $\mathrm{~N} / \mathrm{A}$ & $\mathrm{N} / \mathrm{A}$ & $\downarrow$ & $\begin{array}{l}\downarrow \text { bee midgut lesions; } \\
\uparrow \text { colony strength }\end{array}$ & (55) \\
\hline EtOH L. nobilis Extract & $\downarrow$ & No Effect & $\mathrm{N} / \mathrm{A}$ & N/A & $(56,57)$ \\
\hline C. alba EO extract ${ }^{\star \star}$ & $\downarrow$ & $\uparrow$ & $\mathrm{N} / \mathrm{A}$ & $\mathrm{N} / \mathrm{A}$ & $(58)$ \\
\hline Compounds detected in C. alba EO extract ${ }^{*}$ & $\downarrow$ & $\uparrow$ & $\mathrm{N} / \mathrm{A}$ & $\mathrm{N} / \mathrm{A}$ & $(58)$ \\
\hline $\mathrm{MeOH}$ A. chilensis extract & $\downarrow$ & No Effect & $\mathrm{N} / \mathrm{A}$ & $\mathrm{N} / \mathrm{A}$ & $(59)$ \\
\hline MeOH U. molinae extract & $\downarrow$ & $\uparrow$ & $\mathrm{N} / \mathrm{A}$ & $\mathrm{N} / \mathrm{A}$ & (59) \\
\hline MeOH G. avellana extract & $\downarrow$ & No Effect & $\mathrm{N} / \mathrm{A}$ & $\mathrm{N} / \mathrm{A}$ & $(59)$ \\
\hline $\mathrm{MeOH}$ propolis extract & $\downarrow$ & $\uparrow$ & $\mathrm{N} / \mathrm{A}$ & $\mathrm{N} / \mathrm{A}$ & (59) \\
\hline EtOH propolis extract ${ }^{b}$ & $\downarrow$ & $\uparrow$ & $\mathrm{N} / \mathrm{A}$ & $\mathrm{N} / \mathrm{A}$ & $(60)$ \\
\hline EtOH propolis extract ${ }^{\mathrm{C}}$ & $\downarrow$ & $\uparrow$ & N/A & N/A & $(61)$ \\
\hline BEEWELL AminoPlus & $\downarrow$ & No Effect & $\mathrm{N} / \mathrm{A}$ & 个immune expression & $(62)$ \\
\hline Nozevit ${ }^{\mathrm{d}}$ & $\mathrm{N} / \mathrm{A}$ & $\mathrm{N} / \mathrm{A}$ & $\downarrow$ & $\uparrow$ colony strength & $(63)$ \\
\hline HiveAlive & $\mathrm{N} / \mathrm{A}$ & $\mathrm{N} / \mathrm{A}$ & $\downarrow$ & $\uparrow$ colony strength & (64) \\
\hline \multicolumn{6}{|l|}{ MICROBIAL SUPPLEMENTS } \\
\hline Bacterial surfactin & $\downarrow$ & $\uparrow$ & $\mathrm{N} / \mathrm{A}$ & $\downarrow$ spore viability & (65) \\
\hline L. johnsonii metabolites & $\mathrm{N} / \mathrm{A}$ & $\mathrm{N} / \mathrm{A}$ & $\downarrow$ & $\begin{array}{l}\uparrow \text { fat bodies per bee; } \\
\uparrow \text { colony strength }\end{array}$ & $(66)$ \\
\hline Bifidobacteria & $\downarrow$ & $\mathrm{N} / \mathrm{A}$ & $\mathrm{N} / \mathrm{A}$ & $\mathrm{N} / \mathrm{A}$ & $(67)$ \\
\hline Lactobacilli & $\downarrow$ & $\mathrm{N} / \mathrm{A}$ & $\mathrm{N} / \mathrm{A}$ & $\mathrm{N} / \mathrm{A}$ & $(67)$ \\
\hline P. apium & No Effect & $\uparrow$ & $\mathrm{N} / \mathrm{A}$ & $\mathrm{N} / \mathrm{A}$ & (68) \\
\hline Bacillus sp. & No Effect & $\uparrow$ & $\mathrm{N} / \mathrm{A}$ & $\mathrm{N} / \mathrm{A}$ & $(68)$ \\
\hline Bactocell & No Effect & $\uparrow$ & $\mathrm{N} / \mathrm{A}$ & $\mathrm{N} / \mathrm{A}$ & $(68)$ \\
\hline Levucell SB & No Effect & $\uparrow$ & $\mathrm{N} / \mathrm{A}$ & $\mathrm{N} / \mathrm{A}$ & (68) \\
\hline
\end{tabular}

Treatments not delivered orally are labeled as such. An increase is marked by " $\uparrow$ " and a decrease by " $\downarrow$ ". Metrics that were not measured are labeled non-applicable (N/A).

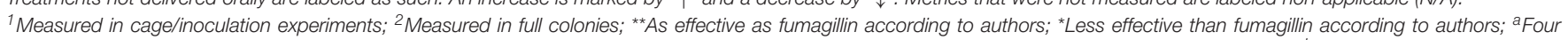

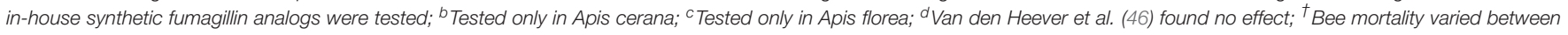
treatments and compound concentrations; $+\beta$-phellandrene, eucalyptol, and $\alpha$-terpineol. 
homologous transcript sequences of a target gene (70). Moreover, RNAi is a natural anti-infective mechanism of the honey bee immune response (71). RNAi is currently being explored for therapeutic activity in human medicine and pesticide activity in agriculture (72-74). Inhibition of varroa mites and several RNA viruses infectious to honey bees has also been accomplished by RNAi (75-82).

Previous work has applied RNAi of Nosema nucleotide transporter genes to control nosemosis in honey bees (51). The genome of $N$. ceranae has been previously sequenced with high specificity of ATP/ADP transporter isoforms (51). ATP/ADP transporter proteins are important for maintaining microsporidian physiological processes (83). This study demonstrated that target transcript levels and host spore loads decrease when honey bees ingest daily doses of synthetic dsRNA (in sugar syrup) specific to $N$. ceranae ATP/ADP transporters (51). In addition, worker bee responsiveness to sucrose (quantified by measuring the proboscis extension reflex), which increases during $N$. ceranae infections (84), decreases at low sucrose concentrations following RNAi treatment. A more recent study used RNAi to lower expression of polar tube protein 3 (ptp3), a protein essential for sporoplasm injection and microsporidian cellular invasion $(32,33,52)$. When $p t p 3$ is knocked down via ingestion of dsRNA, host spore loads decrease, several antimicrobial peptides (Abaecin, apidaecin, hymenoptaecin, defensin-1) normally downregulated by $N$. ceranae infections $(85,86)$ are upregulated, and survival is significantly prolonged (52). The $N$. ceranae Dicer gene has also been identified as a possible RNAi target and may have implications toward minimizing infectivity when knocked down $(87,88)$.

In addition to targeting $N$. ceranae genes specifically, RNAi has been employed to reduce expression of negative regulators of the honey bee immune response (53). It has been shown that $N$. ceranae infections downregulate several immune genes and upregulate the naked cuticle gene $(n k d)$, an antagonist of the WNT pathway and an important regulator of immune function $(53,89-91)$. Following ingestion of dsRNA targeting $n k d$, lower infection levels and increased immune expression and survival are observed in bees (53).

RNAi-mediated knockdown of genes important for $N$. ceranae viability or honey bee immunoregulation may have the potential to control Nosema disease. Nevertheless, several obstacles should be considered when evaluating the feasibility of RNAi-based bee medications. Oral delivery of dsRNA to honey bees may lower RNAi efficiency and stability, as digestive enzymes and gut $\mathrm{pH}$ can rapidly metabolize and alter the drug sequence before delivery to target mRNA (92). A synthetic coating (e.g., nanoparticle/liposome) may provide protection but could also increase production costs (92). Off target and non-specific effects of RNAi are another major concern in agriculture that will likely slow the approval of RNAi-based treatments for apiarian medicine. Although many applications of RNAi have been thoroughly researched, no RNAi-based drugs or pesticides have been approved for agricultural use. The only EPA-approved application of RNAi in agriculture is a strain of corn geneticallymodified to express rootworm-targeting dsRNA (93). RNAi has certainly demonstrated value in identifying potential $N$. ceranae drug targets, but more research is needed in order to show that RNAi as a therapy in the beekeeping industry is safe, costeffective and practical.

\section{EXTRACTS AND NATURAL SUPPLEMENTS}

The effects of organic extracts and natural supplements on $N$. ceranae infections have been extensively explored. Such treatments are attractive to agriculturalists and environmentalists since toxicity is less of a concern compared to other chemical treatments. Indeed, various organic and aqueous natural product extracts have been shown to increase bee survival and lower spore loads following oral treatment (54, 56-61). It should be noted that ethanolic propolis extracts evaluated by Yemor et al. (60) and Suwannapong et al. (61) were tested in different bee species (Apis florea and Apis ceranae) which are globally less important pollinators than honey bees. Natural compounds, particularly flavonoids, have been detected in several plant extracts displaying anti-microsporidian activity in honey bees, although flavonoids have not been confirmed to be the source of this activity (59). Bravo et al. (58) reported in vivo anti-Nosema activity similar to fumagillin in essential oil (EO) hydrodistillation extracts from Cryptocarya alba leaves. Select monoterpenes ( $\beta$ phellandrene, eucalyptol and $\alpha$-terpineol) detected in the extract also inhibited $N$. ceranae (58). Interestingly, the chemical makeup of crude extracts is usually complex and often unknown; for example, plant and propolis extract purity and molecular composition vary greatly between extract batches and sources [e.g., geographical region; (94)]. However, these variations may have a significant effect on product potency. Production of extracts and supplement-based bee treatments must be highly standardized in order to provide confidence of efficacy in the field.

Commercial supplements have been studied for activity against nosemosis. Colonies supplemented with gastric pentadecapeptide BPC 157, a well-studied antiulcer peptide, demonstrate increased worker bee colony population, lower spore counts, and limited lesions to the midgut of infected bees (55). The experiment was not of sufficient length to show an effect on colony survival (55). Additionally, a dietary amino acid and vitamin complex called BEEWELL AminoPlus decreases spore loads and protects honey bees from immune suppression by upregulating expression of antimicrobial peptides (62). Preliminary data suggest that a commercial phytopharmacological supplement, Nozevit ${ }^{\circledR}$, may improve bee health by decreasing colony spore loads (63). Further investigation and a larger sample size is needed in order to confirm these results, as van den Heever et al. (46) reported no effect of Nozevit ${ }^{\circledR}$ in cage trials. A 2-year survey of the seaweed-based supplement HiveAlive ${ }^{\mathrm{TM}}$ reported a decrease in colony spore loads and an increased hive population relative to controls following administration of two biannual treatments (64). Surprisingly, survival was not commented on in this study, notwithstanding the authors account for colony mortality in their analyses of colony strength (64).

Although certain natural extracts and commercial supplements have shown efficacy against $N$. ceranae, there 
are other natural product supplements advertised as antiinfective that do not have any beneficial effects on honey bees infected with $N$. ceranae. Nosestat ${ }^{\circledR}$ and Vitafeed Gold ${ }^{\circledR}$ were evaluated in a field trial and found to have no impact on colony productivity and Nosema spore levels (95). ApiHerb ${ }^{\circledR}$ and Nonosz ${ }^{\circledR}$ are also sold to improve bee health and perhaps treat nosemosis, but additional research and more scientific evidence is needed in order to support claims of efficacy (95). Evidently, beekeepers should be cautious about which supplements and extracts they select for treating $N$. ceranae infections.

\section{MICROBIAL SUPPLEMENTS}

Administering microbial supplements may have positive impacts on honey bee health and impair N. ceranae viability. Baffoni et al. (67) suggest that supplementing the honey bee diet with strains of bifidobacteria and lactobacilli, which secrete antibiotic metabolites, lower $N$. ceranae spore levels. This work adds to previous studies indicating that organic acids and other metabolites (e.g., surfactin) produced by bacteria reduce bee mortality and $N$. ceranae loads when fed to honey bees $(65,66)$. Other bacterial strains and probiotics (Parasaccharibacter apium, Bacillus sp., Bactocell ${ }^{\circledR}$, and Levucell $\mathrm{SB})$ have been shown to improve survival of infected bees but not decrease spore loads (68). A successful anti-Nosema treatment should improve bee health and lower infection levels. Select probiotics, prebiotics, and pollen substitutes

\section{REFERENCES}

1. Gallai N, Salles JM, Settele J, Vaissière BE. Economic valuation of the vulnerability of world agriculture confronted with pollinator decline. Ecol Econ. (2009) 68:810-21. doi: 10.1016/j.ecolecon.2008.06.014

2. Calderone NW. Insect pollinated crops, insect pollinators and US agriculture: trend analysis of aggregate data for the period 1992-2009. PLoS ONE. (2012) 7:e37235. doi: 10.1371/journal.pone.0037235

3. vanEngelsdorp D, Hayes J, Underwood RM, Pettis J. A survey of honey bee colony losses in the U.S., Fall 2007 to Spring 2008. PLoS ONE. (2008) 3:e4071. doi: 10.1371/journal.pone.0004071

4. vanEngelsdorp D, Evans JD, Saegerman C, Mullin C, Haubruge E, Nguyen BK, et al. Colony collapse disorder: a descriptive study. PLoS ONE. (2009) 4:e6481. doi: 10.1371/journal.pone.0006481

5. Klein AM, Vaissière BE, Cane JH, Steffan-Dewenter I, Cunningham SA, Kremen C, et al. Importance of pollinators in changing landscapes for world crops. Proc R Soc B Biol Sci. (2007) 274:303-13. doi: 10.1098/rspb.2006.3721

6. Cox-Foster DL, Conlan S, Holmes EC, Palacios G, Evans JD, Moran NA, et al. A metagenomic survey of microbes in honey bee colony collapse disorder. Science. (2007) 318:283-7. doi: 10.1126/science.1146498

7. Higes M, Martín-Hernández R, Garrido-Bailón E, González-Porto AV, García-Palencia P, Meana A, et al. Honeybee colony collapse due to Nosema ceranae in professional apiaries. Environ Microbiol Rep. (2009) 1:110-3. doi: 10.1111/j.1758-2229.2009.00014.x

8. Le Conte Y, Ellis M, Ritter W. Varroa mites and honey bee health: can Varroa explain part of the colony losses? Apidologie. (2010) 41:353-63. doi: 10.1051/apido/2010017

9. Spivak M, Mader E, Vaughan M, Euliss NH. The plight of the bees. Environ Sci Technol. (2011) 45:34-8. doi: 10.1021/es101468w

10. Cornman RS, Tarpy DR, Chen Y, Jeffreys L, Lopez D, Pettis JS, et al. Pathogen webs in collapsing honey bee colonies. PLoS ONE. (2012) 7:e43562. doi: 10.1371/journal.pone.0043562 may actually exacerbate infections and increase bee mortality (38, 96-98). Alternative methods previously described are likely more promising and applicable to beekeeping than microbial supplements.

\section{CONCLUSION}

Recent laboratory and field studies report encouraging results suggesting that single compounds, RNAi, natural extracts and supplements may impair N. ceranae and improve colony health. It is important that researchers continue to test novel agents for anti-microsporidian activity against nosemosis.

\section{AUTHOR CONTRIBUTIONS}

$\mathrm{AB}$ conceived, designed, and wrote the manuscript.

\section{FUNDING}

The research of $A B$ was unfunded. Open Access manuscript submission fees were funded by the Open Access Publishing Fund, Emory University, Atlanta (United States).

\section{ACKNOWLEDGMENTS}

Thoughtful input and critique regarding the review was provided by Rebecca Ryan and Lily Burnham.

11. Dainat B, vanEngelsdorp D, Neumann P. Colony collapse disorder in Europe. Environ Microbiol Rep. (2012) 4:123-5. doi: 10.1111/j.1758-2229.2011.00312.x

12. Goulson D, Nicholls E, Botías C, Rotheray EL. Bee declines driven by combined Stress from parasites, pesticides, and lack of flowers. Science. (2015) 347:1255957. doi: 10.1126/science. 1255957

13. Higes M, Martín-Hernández R, Botías C, Bailón EG, González-Porto AV, Barrios L, et al. How natural infection by Nosema ceranae causes honeybee colony collapse. Environ Microbiol. (2008) 10:2659-69. doi: 10.1111/j.1462-2920.2008.01687.x

14. Fries I. Nosema ceranae in European honey bees (Apis mellifera). J Invertebr Pathol. (2010) 103(Suppl. 1):S73-9. doi: 10.1016/j.jip.2009.06.017

15. Botías C, Martín-Hernández R, Barrios L, Meana A, Higes M. Nosema spp. infection and its negative effects on honey bees (Apis mellifera iberiensis) at the colony level. Vet Res. (2013a) 44:25. doi: 10.1186/1297-9716-44-25

16. Klee J, Besana AM, Genersch E, Gisder S, Nanetti A, Tam DQ, et al. Widespread dispersal of the microsporidian Nosema ceranae, an emergent pathogen of the western honey bee, Apis mellifera. J Invertebr Pathol. (2007) 96:1-10. doi: 10.1016/j.jip.2007.02.014

17. Paxton RJ, Klee J, Korpela S, Fries I. Nosema cerenae has infected Apis mellifera in Europe since at least 1998 and may be more virulent than Nosema apis. Apidologie. (2007) 38:558-565. doi: 10.1051/apido:2007037

18. Chen Y, Evans JD, Smith IB, Pettis JS. Nosema ceranae is a long-present and wide-spread microsporidian infection of the European honey bee (Apis mellifera) in the United States. J Invertebr Pathol. (2008) 97:186-8. doi: 10.1016/j.jip.2007.07.010

19. Traver BE, Williams MR, Fell RD. Comparison of within hive sampling and seasonal activity of Nosema ceranae in honey bee colonies. J Invertebr Pathol. (2012) 109:187-93. doi: 10.1016/j.jip.2011.11.001

20. Higes M, Meana A, Bartolomé C, Botías C, Martín-Hernández R. Nosema ceranae (Microsporidia), a controversial 21st century honey bee pathogen. Environ Microbiol Rep. (2013) 5:17-29. doi: 10.1111/1758-2229. 12024 
21. Bromenshenk JJ, Henderson CB, Wick CH, Stanford MF, Zulich AW, Jabbour RE, et al. Iridovirus and microsporidian linked to honey bee colony decline. PLoS ONE. (2010) 5:e13181. doi: 10.1371/journal.pone. 0013181

22. Paxton RJ. Does infection by Nosema ceranae cause "Colony Collapse Disorder" in honey bees (Apis mellifera)? J Apic Res. (2010) 49:80-4. doi: 10.3896/IBRA.1.49.1.11

23. Martín-Hernández R, Bartolomé C, Chejanovsky $\mathrm{N}$, Le Conte $\mathrm{Y}$, Dalmon A, Dussaubat C, et al. Nosema ceranae in Apis mellifera: a 12 years postdetection perspective. Environ Microbiol. (2018) 20:1302-29. doi: 10.1111/1462-2920.14103

24. Higes M, García-Palencia P, Martín-Hernández R, Meana A. Experimental infection of Apis mellifera honeybees with Nosema ceranae (Microsporidia). J Invertebr Pathol. (2007) 94:211-7. doi: 10.1016/j.jip.2006.11.001

25. Kralj J, Fuchs S. Nosema sp. influences flight behavior of infected honey bee (Apis mellifera) foragers. Apidologie. (2010) 41:21-8. doi: 10.1051/apido/2009046

26. Goblirsch M, Huang ZY, Spivak M. Physiological and behavioral changes in honey bees (Apis mellifera) induced by Nosema ceranae infection. PLoS ONE. (2013) 8:e58165. doi: 10.1371/journal.pone.0058165

27. Mayack C, Natsopoulou ME, McMahon DP. Nosema ceranae alters a highly conserved hormonal stress pathway in honeybees. Insect Mol Biol. (2015) 24:662-70. doi: 10.1111/imb.12190

28. Li Z, Chen Y, Zhang S, Chen S, Li W, Yan L, et al. Viral infection affects sucrose responsiveness and homing ability of forager honey bees, Apis mellifera $L$. PLoS ONE. (2013) 8:e77354. doi: 10.1371/journal.pone.0077354

29. Badaoui B, Fougeroux A, Petit F, Anselmo A, Gorni C, Cucurachi M, et al. RNA-sequence analysis of gene expression from honeybees (Apis mellifera) infected with Nosema ceranae. PLoS ONE. (2017) 12:e0173438. doi: 10.1371/journal.pone.0173438

30. Li W, Chen Y, Cook SC. Chronic Nosema ceranae infection inflicts comprehensive and persistent immunosuppression and accelerated lipid loss in host Apis mellifera honey bees. Int J Parasitol. (2018) 48:433-44. doi: 10.1016/j.ijpara.2017.11.004

31. Smith ML. The honey bee parasite Nosema ceranae: transmissible via food exchange? PLoS ONE. (2012) 7:e43319. doi: 10.1371/journal.pone.0043319

32. Texier C, Vidau C, Viguès B, El Alaoui H, Delbac F. Microsporidia: a model for minimal parasite-host interactions. Curr Opin Microbiol. (2010) 13:443-9. doi: 10.1016/j.mib.2010.05.005

33. Gisder S, Mockel N, Linde A, Genersch E. A cell culture model for Nosema ceranae and Nosema apis allows new insights into the life cycle of these important honey bee-pathogenic microsporidia. Environ Microbiol. (2011) 13:404-13. doi: 10.1111/j.1462-2920.2010.02346.x

34. Fries I, Granados RR. Intracellular germination of spores of Nosema apis Z. Apidologie. (1992) 23:61-70.

35. Root AI. The ABC and XYZ of Bee Culture. Medina, OH: A I Root Co (2007).

36. Rosenkranz P, Aumeier P, Ziegelmann B. Biology and control of Varroa destructor. J Invertebr Pathol. (2010) 103:S96-S119. doi: 10.1016/j.jip.2009.07.016

37. van den Heever JP, Thompson TS, Curtis JM, Ibrahim A, Pernal SF. Fumagillin: an overview of recent scientific advances and their significance for apiculture. J Agric Food Chem. (2014) 62:2728-37. doi: 10.1021/jf4 055374

38. Pajuelo AG, Torres C, Bermejo FJO. Colony losses: a double blind trial on the influence of supplementary protein nutrition and preventative treatment with fumagillin against Nosema ceranae. J Apic Res. (2008) 47:84-6. doi: 10.1080/00218839.2008.11101429

39. Williams GR, Sampson MA, Shutler D, Rogers REL. Does fumagillin control the recently detected invasive parasite Nosema ceranae in western honey bees (Apis mellifera)? J Invertebr Pathol. (2008) 99:342-4. doi: 10.1016/j.jip.2008.04.005

40. Huang WF, Solter LF, Yau PM, Imai BS. Nosema ceranae escapes fumagillin control in honey bees. PLoS Pathog. (2013) 9:e1003185. doi: 10.1371/journal.ppat.1003185

41. Giacobino A, Rivero R, Molineri AI, Cagnolo NB, Merke J, Orellano E, et al. Fumagillin control of Nosema ceranae (Microsporidia:Nosematidae) infection in honey bee (Hymenoptera:Apidae) colonies in Argentina. Vet Ital. (2016) 52:145-51. doi: 10.12834/VetIt.120.337.6
42. van den Heever JP, Thompson TS, Otto SJG, Curtis JM, Ibrahim A, Pernal SF. The effect of dicyclohexylamine and fumagillin on Nosema ceranae-infected honey bee (Apis mellifera) mortality in cage trial assays. Apidologie. (2016a) 47:663-70. doi: 10.1007/s13592-015-0411-9

43. Mendoza Y, Diaz-Cetti S, Ramallo G, Santos E, Porrini M, Invernizzi C. Nosema ceranae winter control: study of the effectiveness of different fumagillin treatments and consequences on the strength of honey bee (Hymenoptera: Apidae) colonies. J Econ Entomol. (2017) 110:1-5. doi: $10.1093 /$ jee/tow 228

44. Gisder S, Genersch E. Identification of candidate agents active against $N$. ceranae infection in honey bees: Establishment of a medium throughput screening assay based on N. ceranae infected cultured cells. PLoS ONE. (2015) 10:e0117200. doi: 10.1371/journal.pone.0117200

45. Ptaszynska AA, Trytek M, Borsuk G, Buczek K, Rybicka-Jasinska K, Gryko D. Porphyrins inactivate Nosema spp. microsporidia. Sci Rep. (2018) 8:5523. doi: $10.1038 /$ s41598-018-23678-8

46. van den Heever JP, Thompson TS, Otto SJG, Curtis JM, Ibrahim A, Pernal SF. Evaluation of Fumagilin- $B^{\circledR}$ and other potential alternative chemotherapies against Nosema ceranae-infected honeybees (Apis mellifera) in cage trial assays. Apidologie. (2016b) 47:617-30. doi: 10.1007/s13592-01 5-0409-3

47. Underwood RM, Currie RW. Indoor winter fumigation with formic acid for control of Acarapis woodi (Acari: Tarsonemidae) and Nosema sp. disease J Econ Entomol. (2009) 102:1729-36. doi: 10.1603/029.102. 0501

48. Nanetti A, Rodriguez-García C, Meana A, Martín-Hernández R, Higes M. Effect of oxalic acid on Nosema ceranae infection. Res Vet Sci. (2015) 102:16772. doi: 10.1016/j.rvsc.2015.08.003

49. Costa C, Lodesani M, Maistrello L. Effect of thymol and resveratrol administered with candy or syrup on the development of Nosema ceranae and on the longevity of honeybees (Apis mellifera L.) in laboratory conditions. Apidologie. (2010) 41:141-50. doi: 10.1051/apido/2009070

50. Maistrello L, Lodesani M, Costa C, Leonardi F, Marani G, Caldon $\mathrm{M}$, et al. Screening of natural compounds for the control of nosema disease in honeybees (Apis mellifera). Apidologie. (2008) 39:436-45. doi: 10.1051/apido:2008022

51. Paldi N, Glick E, Oliva M, Zilberberg Y, Aubin L, Pettis J, et al. Effective gene silencing in a microsporidian parasite associated with honeybee (Apis mellifera) colony declines. Appl Environ Microbiol. (2010) 76:5960-4. doi: 10.1128/AEM.01067-10

52. Rodríguez-García C, Evans JD, Li W, Branchiccela B, Li JH, Heerman MC, et al. Nosemosis control in European honey bees Apis mellifera by silencing the gene encoding Nosema ceranae polar tube protein 3. J Exp Biol. (2018). 2018:184606. doi: 10.1242/jeb.184606

53. Li W, Evans JD, Huang Q, Rodríguez-García C, Liu J, Hamilton M, et al Silencing the honey bee (Apis mellifera) naked cuticle gene $(n k d)$ improves host immune function and reduces Nosema ceranae infections. Appl Environ Microbiol. (2016) 82:6779-87. doi: 10.1128/AEM.02105-16

54. Roussel M, Villay A, Delbac F, Michaud P, Laroche C, Roriz D, et al. Antimicrosporidian activity of sulphated polysaccharides from algae and their potential to control honeybee nosemosis. Carbohydr Polym. (2015) 133:21320. doi: 10.1016/j.carbpol.2015.07.022

55. Tlak Gajger I, Ribarić J, Smodiš Škerl M, Vlainić J, Sikirić P. Stable gastric pentadecapeptide BPC 157 in honeybee (Apis mellifera) therapy, to control Nosema ceranae invasions in apiary conditions. J Vet Pharmacol. Ther. (2018) 41:614-21. doi: 10.1111/jvp.12509

56. Porrini MP, Fernández NJ, Garrido PM, Gende LB, Medici SK, Eguaras MJ. In vivo evaluation of antiparasitic activity of plant extracts on Nosema ceranae (Microsporidia). Apidologie. (2011) 42:700-7. doi: 10.1007/s13592-01 $1-0076-y$

57. Damiani N, Fernández NJ, Porrini MP, Gende LB, Álvarez E, Buffa F, et al. Laurel leaf extracts for honeybee pest and disease management: antimicrobial, microsporicidal, and acaricidal activity. Parasitol Res. (2014) 113:701-9. doi: 10.1007/s00436-013-3698-3

58. Bravo J, Carbonell V, Sepúlveda B, Delporte C, Valdovinos CE, MartínHernández R, et al. Antifungal activity of the essential oil obtained from Cryptocarya alba against infection in honey bees by Nosema ceranae. J Invertebr Pathol. (2017) 149:141-7. doi: 10.1016/j.jip.2017.08.012 
59. Arismendi N, Vargas M, López MD, Barría Y, Zapata N. Promising antimicrobial activity against the honey bee parasite Nosema ceranae by methanolic extracts from Chilean native plants and propolis. J Apic Res. (2018) 57:522-35. doi: 10.1080/00218839.2018.1453006

60. Yemor T, Phiancharoen M, Benbow EM, Suwannapong G. Effects of stingless bee propolis on Nosema ceranae infected Asian honey bees, Apis cerana. J Apic Res. (2015) 54:468-73. doi: 10.1080/00218839.2016.1162447

61. Suwannapong G, Maksong S, Phainchajoen M, Benbow ME, Mayack C. Survival and health improvement of Nosema infected Apis florea (Hymenoptera: Apidae) bees after treatment with propolis extract. $\mathrm{J}$ Asia $\mathrm{Pa}$ Entomol. (2018) 21:437-44. doi: 10.1016/j.aspen.2018.02.006

62. Glavinic U, Stankovic B, Draskovic V, Stevanovic J, Petrovic T, Lakic N, Stanimirovic Z. Dietary amino acid and vitamin complex protects honey bee from immunosuppression caused by Nosema ceranae. PLoS ONE. (2017) 12:e0187726. doi: 10.1371/journal.pone.0187726

63. Higes M, Gómez-Moracho T, Rodriguez-García C, Botias C, MartínHernández R. Preliminary effect of an experimental treatment with "Nozevit ${ }^{\circledR}$ ". (a phyto-pharmacological preparation) for Nosema ceranae control. J Apic Res. (2014) 53:472-4. doi: 10.3896/IBRA.1.53.4.03

64. Charistos L, Parashos N, Hatjina F. Long term effects of a food supplement HiveAlive $\mathrm{TM}^{\mathrm{TM}}$ on honey bee colony strength and Nosema ceranae spore counts. J Apic Res. (2015) 54:420-6. doi: 10.1080/00218839.2016. 1189231

65. Porrini MP, Audisio MC, Sabaté DC, Ibarguren C, Medici SK, Sarlo EG, et al. Effect of bacterial metabolites on microsporidian Nosema ceranae and on its host Apis mellifera. Parasitol Res. (2010) 107:381-8. doi: 10.1007/s00436-010-1875-1

66. Maggi M, Negri P, Plischuk S, Szawarski N, De Piano F, De Feudis $\mathrm{L}$, et al. Effects of the organic acids produced by a lactic acid bacterium in Apis mellifera colony development, Nosema ceranae control and fumagillin efficiency. Vet Microbiol. (2013) 167:474-83. doi: 10.1016/j.vetmic.2013.07.030

67. Baffoni L, Gaggìa F, Alberoni D, Cabbri R, Nanetti A, Biavati B, et al. Effect of dietary supplementation of Bifidobacterium and Lactobacillus strains in Apis mellifera L. against Nosema ceranae. Benef Microbes. (2016) 7:45-51. doi: 10.3920/BM2015.0085

68. El Khoury S, Rousseau A, Lecoeur A, Cheaib B, Bouslama S, Mercier PL, et al. Deleterious interaction between honeybees (Apis mellifera) and its microsporidian intracellular parasite Nosema ceranae was mitigated by administrating either endogenous or allochthonous gut microbiota strains. Front Ecol Evol. (2018) 6:58. doi: 10.3389/fevo.2018.00058

69. Upadhya R, Zhang HS, Weiss LM. System for expression of microsporidian methionine amino peptidase type 2 (MetAP2) in the yeast Saccharomyces cerevisiae. Antimicrob Agents Chemother. (2006) 50:3389-95. doi: 10.1128/AAC.00726-06

70. Fire A, Xu S, Montgomery MK, Kostas SA, Driver SE, Mello CC. Potent and specific genetic interference by double-stranded RNA in caenorhabditis elegans. Nature. (1998) 391:806-11.

71. Brutscher LM, Flenniken ML. RNAi and antiviral defense in the honey bee. $J$ Immunol Res. (2015) 2015:941897. doi: 10.1155/2015/941897

72. Yu N, Christiaens O, Liu J, Niu J, Cappelle K, Caccia S, et al. Delivery of dsRNA for RNAi in insects: an overview and future directions. Insect Sci. (2013) 20:4-14. doi: 10.1111/j.1744-7917.2012.01534.x

73. Pereira TC, Lopes-Cendes I. Medical applications of RNA interference (RNAi). BMC Proc. (2013) 7:(Suppl. 2):K21. doi: 10.1186/1753-65 61-7-S2-K21

74. Zhang J, Khan SA, Heckel DG, Bock R. Next-generation insect-resistant plants: RNAi-mediated crop protection. Trends Biotechnol. (2017) 35:871-82. doi: 10.1016/j.tibtech.2017.04.009

75. Aronstein K, Pankiw T, Saldivar E. SID-I is implicated in systemic gene silencing in the honey bee. I Apic Res. (2006) 45:20-4. doi: 10.1080/00218839.2006.11101307

76. Maori E, Paldi N, Shafir S, Kalev H, Tsur E, Glick E, et al. IAPV, a bee-affecting virus associated with colony collapse disorder can be silenced by dsRNA ingestion. Insect Mol Biol. (2009) 18:55-60. doi: 10.1111/j.1365-2583.2009.00847.x

77. Campbell EM, Budge GE, Bowman AS. Gene-knockdown in the honey bee mite Varroa destructor by a non-invasive approach: studies on a glutathione S-transferase. Parasit Vectors. (2010) 3:73. doi: 10.1186/1756-33 05-3-73

78. Hunter W, Ellis J, Vanengelsdorp D, Hayes J, Westervelt D, Glick E, et al. Large-scale field application of RNAi technology reducing Israeli acute paralysis virus disease in honey bees (Apis mellifera, hymenoptera: Apidae). PLoS Pathog. (2010) 6:e1001160. doi: 10.1371/journal.ppat. 1001160

79. Desai SD, Eu YJ, Whyard S, Currie RW. Reduction in deformed wing virus infection in larval and adult honey bees (Apis mellifera L.) by double-stranded RNA ingestion. Insect Mol Biol. (2012) 21:446-55. doi: 10.1111/j.1365-2583.2012.01150.x

80. Garbian Y, Maori E, Kalev H, Shafir S, Sela I. Bidirectional transfer of RNAi between honey bee and Varroa destructor: varroa gene silencing reduces varroa population. PLoS Pathog. (2012) 8:e1003035. doi: 10.1371/journal.ppat.1003035

81. Chen YP, Pettis JS, Corona M, Chen WP, Li CJ, Spivak M, et al. Israeli acute paralysis virus: epidemiology, pathogenesis and implications for honey bee health. PLoS Pathog. (2014) 10:e1004261. doi: 10.1371/journal.ppat. 1004261

82. Zhang J, Zhang Y, Han R. The high-throughput production of dsRNA against sacbrood virus for use in the honey bee Apis cerana (Hymenoptera: Apidae). Virus Genes. (2016) 52:698-705. doi: 10.1007/s11262-016-1346-6

83. Tsaousis AD, Kunji ERS, Goldberg AV, Lucocq JM, Hirt RP, Embley TM. A novel route for ATP acquisition by the remnant mitochondria of Encephalitozoon cuniculi. Nature. (2008) 453:553-6. doi: 10.1038/nature06903

84. Mayack C, Naug D. Energetic stress in the honeybee Apis mellifera from Nosema ceranae infection. J Invertebr Pathol. (2009) 100:185-8. doi: 10.1016/j.jip.2008.12.001

85. Antúnez K, Martín-Hernández R, Prieto L, Meana A, Zunino P, Higes M. Immune suppression in the honey bee (Apis mellifera) following infection by Nosema ceranae (Microsporidia). Environ Microbiol. (2009) 11:2284-90. doi: 10.1111/j.1462-2920.2009.01953.x

86. Chaimanee V, Chantawannakul P, Chen Y, Evans JD, Pettis JS. Differential expression of immune genes of adult honey bee (Apis mellifera) after inoculated by Nosema ceranae. J Insect Physiol. (2012) 58:1090-5. doi: 10.1016/j.jinsphys.2012.04.016

87. Holt HL, Aronstein KA, Grozinger CM. Chronic parasitization by Nosema microsporidia causes global expression changes in core nutritional, metabolic and behavioral pathways in honey bee workers (Apis mellifera). BMC Genomics. (2013) 14:799. doi: 10.1186/1471-2164-14-799

88. Evans JD, Huang Q. Interactions among host-parasite microRNAs during Nosema ceranae proliferation in Apis mellifera. Front Microbiol. (2018) 9:698. doi: 10.3389/fmicb.2018.00698

89. Zeng W, Wharton KA, Mack JA, Wang K, Gadbaw M, Suyama K, et al. naked cuticle encodes an inducible antagonist of Wnt signalling. Nature. (2000) 403:789-95. doi: 10.1021/cm062167i

90. Gordon MD, Dionne MS, Schneider DS, Nusse R. WntD is a feedback inhibitor of Dorsal/NF- $\kappa$ B in Drosophila development and immunity. Nature. (2005) 437:746-9. doi: 10.1038/nature04073

91. Staal FJT, Luis TC, Tiemessen MM. WNT signalling in the immune system: WNT is spreading its wings. Nat Rev Immunol. (2008) 8:581-93. doi: $10.1038 /$ nri2360

92. Mamta B, Rajam MV. RNAi technology: a new platform for crop pest control. Physiol Mol Biol Plants. (2017) 23:487-501. doi: 10.1007/s12298-01 7-0443-x

93. Zotti M, dos Santos EA, Cagliari D, Christiaens O, Taning CNT, Smagghe G. RNA interference technology in crop protection against arthropod pests, pathogens and nematodes. Pest Manag Sci. (2018) 74:1239-50. doi: $10.1002 /$ ps.4813

94. Huang S, Zhang CP, Wang $\mathrm{K}$, Li GQ, Hu FL. Recent advances in the chemical composition of propolis. Molecules. (2014) 19:19610-32. doi: 10.3390/molecules191219610

95. Botías C, Martín-Hernández R, Meana A, Higes M. Screening alternative therapies to control Nosemosis type $\mathrm{C}$ in honey bee (Apis mellifera iberiensis) colonies. Res Vet Sci. (2013b) 95:1041-5. doi: 10.1016/j.rvsc.2013. 09.012

96. Fleming JC, Schmehl DR, Ellis JD. Characterizing the impact of commercial pollen substitute diets on the level of Nosema spp. in 
Honey Bees (Apis mellifera L.). PLoS ONE. (2015) 10:e0132014. doi: 10.1371/journal.pone.0132014

97. Ptaszynska AA, Borsuk G, Zdybicka-Barabas A, Cytrynska M, Małek W. Are commercial probiotics and prebiotics effective in the treatment and prevention of honeybee nosemosis C? Parasitol Res. (2016) 115:397-406. doi: $10.1007 / \mathrm{s} 00436-015-4761-\mathrm{z}$

98. Mortensen AN, Jack CJ, Bustamante TA, Schmehl DR, Ellis JD. Effect of supplemental pollen feeding on honey bees (Hymenoptera: Apidae) colony strength and Nosema spp. infection. J Econ Entomol. (2018) 112:60-6. doi: $10.1093 /$ jee/toy341
Conflict of Interest Statement: The author declares that the research was conducted in the absence of any commercial or financial relationships that could be construed as a potential conflict of interest.

Copyright (0) 2019 Burnham. This is an open-access article distributed under the terms of the Creative Commons Attribution License (CC BY). The use, distribution or reproduction in other forums is permitted, provided the original author $(s)$ and the copyright owner(s) are credited and that the original publication in this journal is cited, in accordance with accepted academic practice. No use, distribution or reproduction is permitted which does not comply with these terms. 